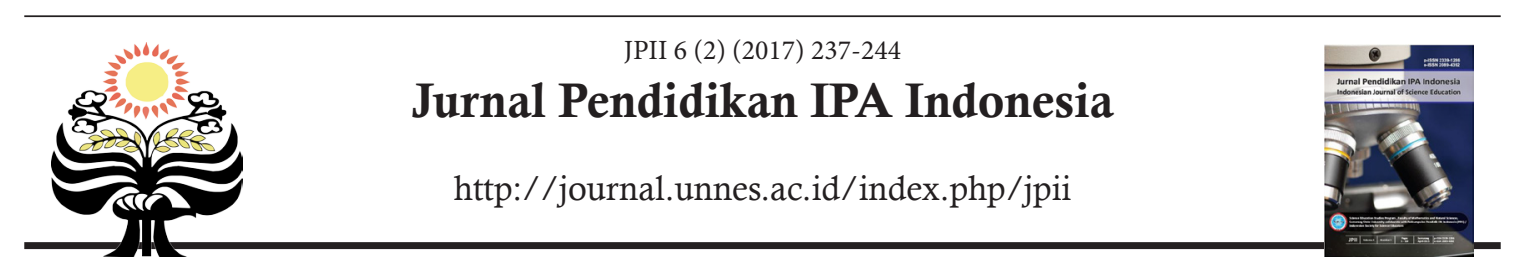

\title{
ENHANCEMENT OF SCIENCE STUDENTS' PROCESS SKILLS THROUGH IMPLEMENTATION OF GREEN LEARNING METHOD (GeLeM) WITH CONSERVATION-BASED INQUIRY APPROACH
}

\author{
E. N. Savitri*1, I. U. Wusqo' ${ }^{1}$, M. W. Ardhi' ${ }^{2}$, P. D. Putra ${ }^{3}$ \\ ${ }^{1}$ Department of Integrated Science, Faculty of Mathematics and Natural Sciences, \\ Universitas Negeri Semarang, Indonesia \\ ${ }^{2}$ Department of Biology Education, FKIP, Universitas PGRI Madiun, Indonesia \\ ${ }^{3}$ Educational Division, Graduate School of Science and Technology, Shizuoka University, Japan
}

DOI: 10.15294/jpii.v6i2.11286

Accepted: March 28 ${ }^{\text {th }}, 2017$. Approved: July 30"th 2017. Published: October $17^{\text {th }}, 2017$.

\begin{abstract}
The inquiry of science teaching aims to encourage the ability to think, work and be scientific and communicate as an important aspect of life skills. Inquiry learning with Green Learning Method (GeLeM) focuses on the ability to think, work and be scientific. The data collection was conducted in the Department of Integrated Science, Faculty of Mathematics and Natural Sciences (FMIPA), Universitas Negeri Semarang on the course of General Biology, even semester of the academic year 2016/2017. The results show that application of method "GeLeM" can increase the average of cognitive value, learning response and the ability of students' Science Process Skill (SPS) in science learning especially biology in the material of the diversity of living creatures. Common biology lectures that use the method of Green Learning Method (GeLeM) can be collaborated with instilling conservation horizon on the students. The conclusion of this study is that Green Learning Method (GeLeM) can improve student cognitive result and science process skill in science learning. In addition, students are also able to find the concept that comes from the environment (nature), students can also love and care for the environment as a vehicle for learning.
\end{abstract}

(C) 2017 Science Education Study Program FMIPA UNNES Semarang

Keywords: Science Process Skill (SPS); Green Learning Method (GeLeM); inquiry; conservation

\section{INTRODUCTION}

Science Learning (Science) has an important position in the development of the character of society and nation due to the progress of science which is growing very rapidly, the position of science that can be transferred in other fields, as well as science which contained the content of values and attitudes on which the formation of human character (Widowati, 2017). The process of learning science should include three aspects that must be obtained by students, namely the skills of cognitive thinking (minds on), psychomotor skills (hands on), and social skills (hearts on).

\footnotetext{
*Address Correspondence:

E-mail: ernanoorsavitri@mail.unnes.ac.id
}

Science learning provides an opportunity to describe objects and events, ask questions, gain knowledge, and construct explanations of natural phenomena, test explanations of natural phenomena, test explanations in various ways and communicate them to others (Wahyuni, et al., 2017). Thus, knowledge of science is obtained through a process using scientific methods and provides opportunities for learning experiences, for example through reading, discussion, experimenting, making a summary and observing natural phenomena (Ngabekti, et al., 2017). Knowledge of science is obtained through a process using scientific methods. It provides an opportunity to gain learning experience through reading, discussion, experimenting, making a summary, and observing natural phenomena (Sayekti et al., 2012). 
Inquiry learning is one effective learning approach that can help students improve thinking skills by using higher mental processes and critical thinking skills (Astuti et al., 2013). According Yuniyanti et al., (2012), inquiry learning aims to provide a way for students to build intellectual skills (thinking skills) related to reflective thinking processes. If thinking is the main goal of education, then there must be ways to help individuals to build that ability.

The inquiry learning stages are identifying and asking questions, designing and conducting experiments, analyzing data and evidence, explaining and delivering the findings. This is in harmony with the skills that form the foundation for applying the scientific method or otherwise known as the science process skill. In addition to emphasizing the process of discovery (inquiry), science learning will also be more meaningful if it is done without overriding the principles of conservation so that it can form a character that cares about the environment and local culture (conservation). It is intended that the learning from the environment is still runningand the environment can be well maintained. Learning by using inquiry approach according to Towndrow et al., (2008) is part of science.

According Trianto (2007) inquiry strategy means a series of learning activities that involve maximally all the ability to search and investigate the systematic, critical, logical, and analysis so that it can formulate their own concept of the discovery with full confidence. The main targets of inquiry learning activities are (1) maximal student involvement in the learning process; (2) logical and systematic activity harassment on learning objectives; (3) developing students' selfconfidence about what is found in the inquiry process.

According to Putra (2013) inquiry can be grouped into 3, namely: guided inquiry Approa$\mathrm{ch}$, free inquiry, and free modified inquiry. All inquiry activities involve process skills that include basic process skills, measurement and calculation skills, experimental planning skills, and the skills of processing and presenting data (Nur, 2011). Learning by inquiry method in the laboratory is also very effective in developing the skills of students' science process schools (Khan \& Iqbal, 2011).

Green Learning refers to the Green Teacher learning model that has been coined and adopted from the term green teacher which was launched on February 28th, 2009 with the support of the Ministry of Environment. By referring to the operational explanation of the green teacher, the concept of operational expression of green learning in the concept of college learning is (a) to give students the opportunity to develop a personal relationship with nature to provide student more knowledge as a teacher candidate; (b) to emphasize the relationship with other people or species; (c) future-oriented; (d) proficient use of mass media (ICT); (e) to include traditional knowledge and local wisdom; (f) to integrate several related disciplines; (g) awareness in learning in nature; (h) to utilize natural resources as a source of learning (Ardhi et al., 2014)

The use of GeLeM method can build cognitive aspect through concept discovery activity. The affective aspect can be built through cooperation activities among students at the time of learning, while in psychomotor aspects; inquiry learning is able to grow students' skills in working scientifically. Scientific work skills are undertaken by students in science learning, especially in general biology courses. These skills referred to science process skills (Ardhi et al., 2014).

Scientific process skills can be interpreted as an insight into the development of intellectual, social, and physical skills that come from the fundamental ability that already exists. Scientific process skills provide a proper understanding of the nature of science and can experience the stimulus of knowledge (Dimyati \& Mudjiono, 2009). According to Wibowo et al. (2013), process skill is a teaching-learning approach that leads to the development of fundamental mental, physical and social abilities as a driver of higher abilities within an individual. The process skill approach emphasizes the growth and development of certain skills in an individual so that they are able to process the information to discover new and useful things in the form of facts, concepts and the development of attitudes and values. Scientific process skills according to Yulianti \& Wiyanto, (2009) is the ability or ability to carry out an action in learning science so as to produce concepts, theories, principles, laws, or facts or evidence.

Yulianti \& Wiyanto (2009) divide the process skills into basic science process skills and integrated science process skills. According to Dewi (2008), basic science process skills consist of six skills, namely observation skills, classification skills, communication skills, measurement skills, prediction skills, and inference skills.

There has been a lot of research done by using natural media around, but the method of Green Learning is a method of learning in nature that uses natural media in learning as well as invites students to recognize and analyze environmental problems used as learning resources. The 
objective of this research is to know the improvement of science process skill and the improvement of cognitive learning result of IPA students as implementation of Green Learning Method (GeLeM) with conservation-based inquiry approach.

\section{METHODS}

This research is a classroom action research, conducted in accordance with student lecture schedule to obtain optimal results through the most effective way and procedure. This research is defined as one form of research that is reflective with the reasons to perform certain actions in order to improve the quality of learning in the classroom.

Data collection was conducted at Integrated Science Department, Faculty of Mathematics and Natural Sciences (FMIPA) Universitas Negeri Semarang in the subject General Biology course, even semester of the academic year 2016/2017. Population in this research is all students of even semester in Integrated Science Department of FMIPA UNNES who take general biology course in the even semester of the academic year 2016/2017. The research subjects consist of 68 students who are divided into group 1 and group 2. Samples are taken by using purposive sampling technique. The chosen subjects were students from group 2 consisting of 34 students.

The implementation stage of this research consists of several stages, namely observation, reflection and evaluation. Qualitative data were analyzed using flow method. The paths in the qualitative data analysis include: data reduction, data presentation and conclusion (Sugiyono, 2013).

\section{RESULTS AND DISCUSSIONS}

Classroom action research was carried out for 3 cycles through the implementation of 1 time face to face which is a cycle of action learning. Any findings obtained during each cycle during specific learning activities will be observed in the aspects of cognitive assessment, learning response questionnaire, and observation of SPS capability in each student in an experimental class.

\section{Pre-Cycle Stage}

Learning activities at the pre-cycle stage were conducted using discussion and question and answer method without using "Green Learning Method". The result of the students' evaluation at the pre cycle stage can be seen in Table 1 .

Table 1. Score Distribution of Pre-Cycle Stage

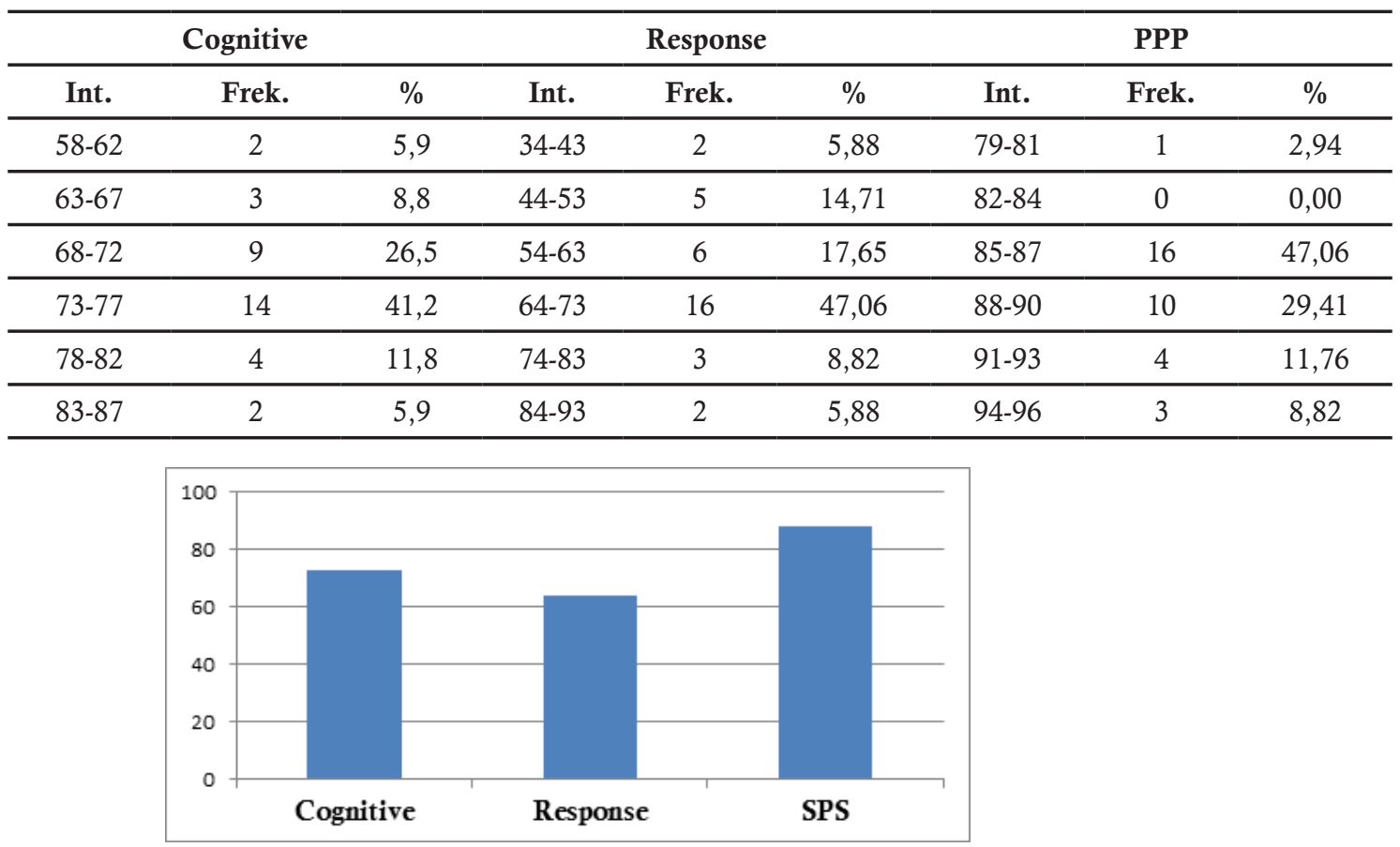

Figure 1. Class Average Score in the Pre-Cycle Stage 
The results of the pre-cycle learning achievement in Figure 1 show that the achievement of cognitive values is mostly obtained by the students at the interval of 73-77 and many others are in the 68-72 intervals. This shows the need to improve the quality of learning to improve student learning outcomes, one of which is done by using the method of learning "Green Learning" (GeLeM) which is implemented in several cycles to get quality learning outcomes.

Learning outcomes to be achieved in this study is that most students get a minimum value of $\mathrm{AB}$ (interval value 81-85). In addition to cognitive results, observations of learning responses are also conducted. The following is the result of students' learning response on achievement in pre cycle stage.

The condition of the learning response on the pre cycle of value dominance is at $64-73$ value intervals. The circumstances indicate that the learning can still be improved in order to increase student responses to learning. Efforts are made by applying the learning method "GeLeM".

With this method, it is expected that there will be an increase in student cognitive outcomes as well as a good response at the time of learning (students are interested in attending lectures). In addition to cognitive results, the students' science process skill (SPS) is also assessed.
The value of SPS in the pre cycle stage indicates that the most value group is at the 85-87 value interval. However, the distribution of the values is not evenly distributed. There are still students who are at interval 79-81 so it is still possible to increase the student's SPS.

\section{Cycle 1 Stage}

In the learning activity of cycle 1 , the material of Protista was held in 1 meeting. In accordance with the planning in RPS, learning activities has been implemented by applying the Green Learning Method using observation methods and surrounding environmental media. At Protista's learning, students took samples from the environment to be observed using a microscope. Samples are taken from the surrounding environment in the form of wetland water and potential river water containing species from Kingdom Protista to be observed.

At the time of sampling, students are invited to observe the environment and analyze the environment. If the students observed the environmental problem, then they were immediately asked to discuss to solve the problem. Then the results of observations under the microscope were drawn on the worksheet that has been provided. The result of recapitulation of student achievement in cycle 1 can be seen in Table 2 .

Table 1. Distribution of Students' Scores in the First Cycle

\begin{tabular}{ccccccccc}
\hline & Cognitive & \multicolumn{3}{c}{ Response } & \multicolumn{3}{c}{ SPS } \\
\hline Int. & Frek. & $\%$ & Int. & Frek. & $\%$ & Int. & Frek. & $\%$ \\
\hline $59-64$ & 7 & 20,6 & $54-59$ & 2 & 5,88 & $82-83$ & 6 & 17,65 \\
$65-70$ & 5 & 14,7 & $60-65$ & 3 & 8,82 & $84-85$ & 3 & 8,82 \\
$71-76$ & 7 & 20,6 & $66-71$ & 10 & 29,41 & $86-87$ & 4 & 11,76 \\
$77-82$ & 9 & 26,5 & $72-77$ & 12 & 35,29 & $88-89$ & 7 & 20,59 \\
$83-88$ & 5 & 14,7 & $78-83$ & 5 & 14,71 & $90-91$ & 6 & 17,65 \\
$89-94$ & 1 & 2,9 & $84-89$ & 2 & 5,88 & $92-93$ & 8 & 23,53 \\
\hline
\end{tabular}

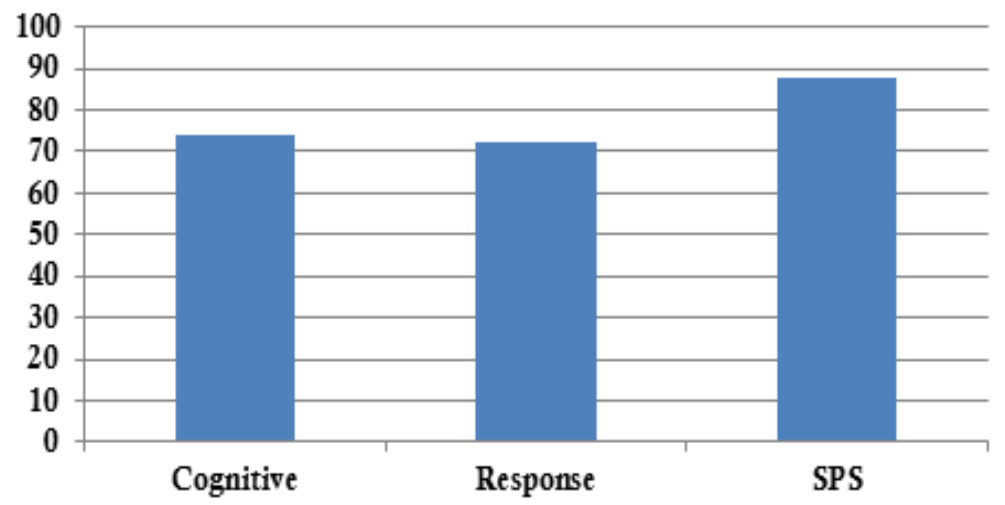

Figure 2. Class Average Scores in the First Cycle 
In learning activity of cycle 1 , achievement of cognitive value is in value group with value limit above 77 equal to $44,1 \%$, while value limit below 76 equal to $55.9 \%$. The condition has not shown any significant improvement from pre-cycle. This can happen because students are still in adjustment to the application of learning with the method "GeLeM". Learning atmosphere in the first cycle of the first time applied method "GeLeM", so generally, there is a decline in scores of pre-cycle that has not applied method "GeLeM".

For class avreage score, cycle 1 achieved 74 which indicates a slight increase from pre-cycle average of 73. This is because in the interval group, the scores above 77 increase in terms the the number of frequencies. In addition to cognitive assessment, assessment of learning responses is also performed. It aims to determine the student's response to the learning that was conducted with Green Learning Method. Based on the learning response, the dominant scores of the 1st cycle is at intervals of $72-77$ with a percentage of $35.29 \%$. There is an increase of pre-cycle dominant scores in the 64-73 score group with a percentage of $47.06 \%$. The condition shows that the "GeLeM" method of learning is well received by students, compared to the practicum method and discussion without using "GeLeM" method.

The ability of SPS students in cycle 1 increased compared to pre-cycle, ie there was an increase in the number of students who had achieved the value of Skills Process of Science (SPS) above 90, the condition indicates a positive relationship between "GeLeM" learning method and the skill that is mastered by students during practicum activities.

\section{Cycle 2}

The learning activity of cycle 2 about Plantae material was held in 1 meeting. In accordance with the planning in RPS, the meeting has implemented learning activities by applying the Green Learning Method using observation methods and surrounding environmental media. In learning Plantae, students observe the diversity of plants that exist in the environment around the campus in this case the Faculty of Mathematics and Natural Sciences. After observation, the students draw the observed plant species and give the organ's information on the plant species. At the time of observation, the students also observed the surrounding environment, analyzed the environmental problems found and collected waste at the time of observation. It aims to make students more concerned about the cleanliness of the surrounding environment. In addition, the students also separated the organic and non-organic waste found. The result of recapitulation of student achievement in cycle 2 can be seen in Table 3 .

In learning activity of cycle 2 , achievement of cognitive score is in score group with scores above 78 equal to $58,8 \%$, while score limit below 77 equal to $41.2 \%$. These conditions have shown a significant increase of the cycle. This means that the students are getting used to using the "GeLeM" method and the value interval also shows that the "GeLeM" method is able to improve students' cognitive value in understanding the material of the diversity of living creatures especially on Kingdom Plantae material. The class average score in cycle 1 reached 74 while in cycle 2 reached 78 . Based on the learning response in cycle 2 , the dominant value was in the interval group of 71-79 with the percentage of 44.12, an increase from cycle 1 which dominant score was in the interval of 72-77 with percentage of $35.29 \%$. The situation shows that the learning method "GeLeM" can be well received on the students, and influential both in learning. Good response from students shows that students interested in understanding the material by using "GeLeM" learning method.

Table 3. Distribution of student scores of cycle 2

\begin{tabular}{ccccccccc}
\hline & Cognitif & \multicolumn{3}{c}{ Response } & \multicolumn{3}{c}{ SPS } \\
\hline Int. & Frek. & $\%$ & Int. & Frek. & $\%$ & Int. & Frek. & $\%$ \\
\hline $63-67$ & 2 & 5,9 & $44-52$ & 1 & 2,94 & $79-81$ & 1 & 2,94 \\
$68-72$ & 3 & 8,8 & $53-61$ & 6 & 17,65 & $82-84$ & 0 & 0,00 \\
$73-77$ & 9 & 26,5 & $62-70$ & 3 & 8,82 & $85-87$ & 3 & 8,82 \\
$78-82$ & 13 & 38,2 & $71-79$ & 15 & 44,12 & $88-90$ & 10 & 29,41 \\
$83-87$ & 4 & 11,8 & $80-88$ & 5 & 14,71 & $91-93$ & 13 & 38,24 \\
$88-92$ & 3 & 8,8 & $90-98$ & 4 & 11,76 & $94-96$ & 7 & 20,59 \\
\hline
\end{tabular}




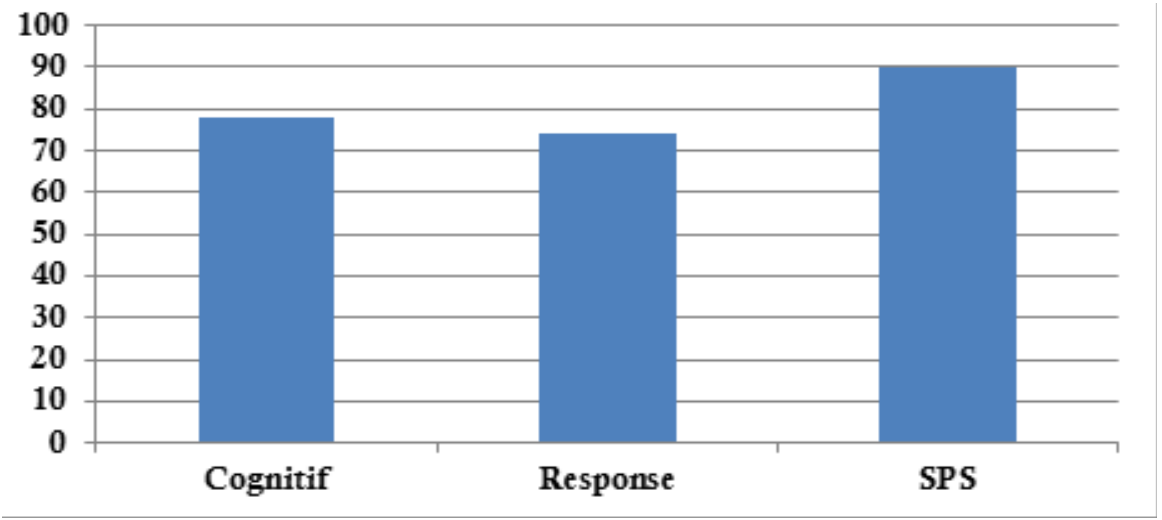

Figure 3. Class Average Scores of Cycle 2

The method can be applied well to improve students cognitive ability. The ability of SPS of students in cycle 2 increased compared to cycle 1 , that is an increase of the number of students who succeeded in achieving the value of Science Processing Skills (SPS) $\geq 90$. In cycle 1 , the group score $\geq 90$ was $41.18 \%$ while in cycle 2 was $58,83 \%$. The condition indicates a positive correlation between "GeLeM" method of learning method and the science skill that is controlled by the students during the learning activity with "GeLeM" method.

Application of the "GeLeM" method can spur the increase of SPS to the students. The results of cognitive learning and the ability of the student science process obtained up to cycle 2 have increased significantly. However, it is necessary to carry out the next cycle to find out the continuity of the action, so it can be assured that learning by applying the "GeLeM" method can still improve the cognitive and SPS scores in the next lesson.

\section{Cycle 3}

The activity of learning cycle 3 about the material Animalia was held in 1 meeting. In ac- cordance with the planning in RPS, the meeting implemented learning activities by applying the Green Learning Method using observation methods and surrounding environmental media. In Animalia learning, students observed the diversity of animalia present in forests and beaches. After observation, students draw animals observed and give information to the organ of the animal species. At the time of observation, the students also observed the surrounding environment, analyzed the environmental problems found and collected waste at the time of observation. Here is a recapitulation of student cognitive achievement in cycle 3 . The result of recapitulation of student achievement in cycle 3 can be seen in Table 4 .

Learning activity in cycle 3 achieved cognitive scores above 78 equal to $85,3 \%$, while scores below 77 equal to $58,8 \%$. These conditions have shown a significant increase of the cycle. This means that the students are getting used to using the "GeLeM" method and the score interval also shows that the "GeLeM" method is able to improve students' cognitive value in understanding the material of the diversity of living creatures especially on Kingdom Plantae material.

Table 4. Student Score Distribution of Cycle 3

\begin{tabular}{ccccccccc}
\hline & Cognitive & \multicolumn{3}{c}{ Response } & \multicolumn{3}{c}{ SPS } \\
\hline Int. & Frek. & $\%$ & Int. & Frek. & $\%$ & Int. & Frek. & $\%$ \\
\hline $74-77$ & 5 & 14,7 & $79-82$ & 4 & 11,76 & $84-85$ & 1 & 2,94 \\
$78-81$ & 9 & 26,5 & $83-86$ & 10 & 29,41 & $86-87$ & 0 & 0,00 \\
$82-85$ & 8 & 23,5 & $87-90$ & 13 & 38,24 & $88-89$ & 1 & 2,94 \\
$86-89$ & 6 & 17,6 & $91-94$ & 4 & 11,76 & $90-91$ & 6 & 17,65 \\
$90-93$ & 4 & 11,8 & $95-98$ & 2 & 5,88 & $92-93$ & 10 & 29,41 \\
$94-97$ & 2 & 5,9 & $99-100$ & 1 & 2,94 & $94-95$ & 16 & 47,06 \\
\hline
\end{tabular}




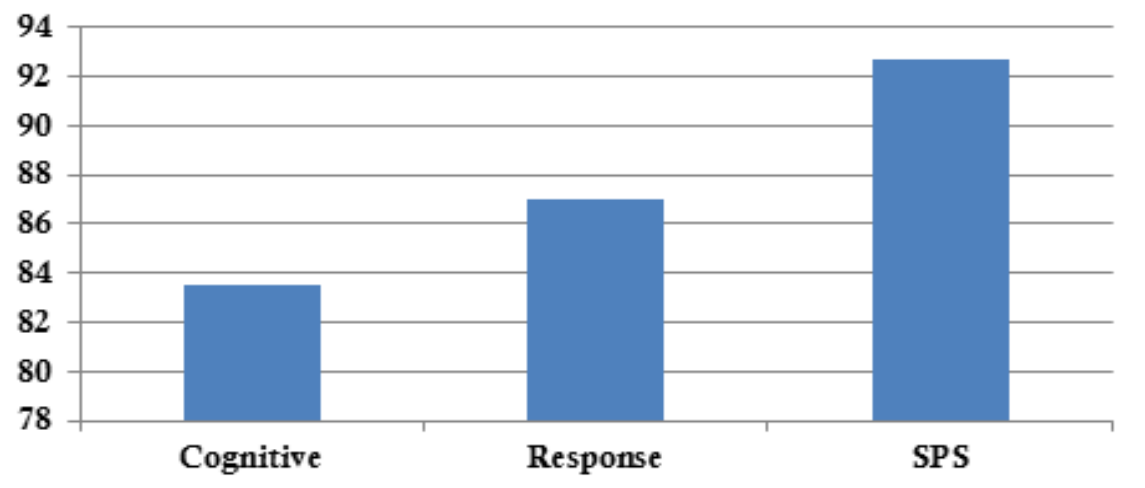

Figure 4. Class Average Value of Cycle 3

The class average score in cycle 1 reached 74 while in cycle 2 reached 78 . This shows a significant increase of the average value of the class. During the learning activities, assessment of the learning response is still carried out.

The dominant score based on learning responses in cycle 3 is in the interval group score of $87-90$ with the percentage of $38.24 \%$ which increase from cycle 2 which dominant score is in the interval group score of 71-79 with the percentage of $44.12 \%$. The condition shows that the learning method "GeLeM" can still be well received on the students, and it became good influence in learning.

The student's SPS capability in cycle 3 increased compared to cycle 1 , which is the increase of the number of students who achieved the value of Science Skills Processing (SPS) $\geq 90$. In cycle 2 , the group value of $\geq 90$ is $58.83 \%$ while in cycle 3 is $94,12 \%$. the condition indicates a positive correlation between "GeLeM" learning method and the science skill that is controlled by the students during the learning activity with "GeLeM" method. This means that the more frequently applied the method, the more the students are trained in observation and other science activities. It improved students' science process skills to become better. The results of cognitive learning and the ability of the student science process obtained up to cycle 3 have increased constantly and significantly so that the cycle can be stopped.

Learning by applying the method "GeLeM" can increase the cognitive and SPS values in science learning, especially biology in the material of diversity of living things.

\section{CONCLUSION}

The concept of operational elaboration of Green Learning Method (GeLeM) in the concept of learning in universities is to give students opportunities to develop personal relationships with nature as an aspect that a teacher candidate should have. This concept also emphasized relationships with other people or species and activities of human beings on the planet, helped students move from a "direct-to-face" to futuristic-oriented, helped improve them in using mass media and (ICT) experience, included traditional knowledge and local wisdom, integrated multiple related disciplines, fostered consciousness in learning nature, as well as utilized natural resources as a source of learning.

Common biology lectures that use the method of Green Learning Method (GeLeM) can be collaborated with the planting of conservation insights on the students. In this study, the students are able to find the concept that comes from the environment (nature), students can also love and care for the environment as a vehicle for learning. Learning by applying the "GeLeM" method can improve the average of cognitive score, learning responsiveness and the ability of student SPSs in science learning especially biology in the material of diversity of living things.

\section{REFERENCES}

Ardhi, M. W., Yuhanna, W. L., \& Prabowo, S. A. (2014, December). Implementasi Green Learning Method (GeLem) dalam Pengembangan Bahan Ajar Berbasis Potensi Lokal di Wana Wisata Grape, Kecamatan Wungu, Kabupaten Madiun. In Prosiding SNPS (Seminar Nasional Pendidikan Sains) (Vol. 1).

Astuti, Y., \& Setiawan, B. (2013). Pengembangan Lembar Kerja Siswa (LKS) Berbasis Pendekatan Inkuiri Terbimbing Dalam Pembelajaran Kooperatif Pada Materi Kalor. Jurnal Pendidikan IPA Indonesia, 2(1), 15-22.

Dewi, S. (2008). Keterampilan Proses Sains. Bandung: Tinta Emas Publishing.

Dimyati, \& Mudjiono. (2009). Belajar dan Pembelajaran. Jakarta: Rineka Cipta. 
Khan, M., \& Iqbal, M. Z. (2011). Effect of Inquiry Lab Teaching Method on the Development of Scientific Skills Through the Teaching of Biology in Pakistan. Language in India, 11(1), 169-178.

Ngabekti, Sri., Saiful Ridlo., Peniati, Martanto. (2017). Meta-analysis of Jelajah Alam Sekitar (JAS) Approach Implementation in Learning Procces. Jurnal Pendidikan IPA Indonesia, Vol 6(1), 153-164.

Nur, M. (2011). Modul keterampilan-keterampilan proses sains. Universitas Negeri Surabaya Pusat Sains dan Matematikan Sekolah, Surabaya.

Putra, S. R. (2013). Desain belajar mengajar kreatif berbasis sains. Jogjakarta: Diva Perss.

Sayekti, IC., Sarwanto., Suparmi. (2012). Pembelajaran IPA Menggunakan Pendekatan Inkuiri terbimbing Melalui Metode Eksperimen dan Demonstrasi Ditinjau dari Kemampuan Analisis dan Sikap Ilmiah Siswa. Jurnal Inkuiri Vol 1 (2), 142-153

Sugiyono. (2013). Metode Penelitian Pendidikan Pendekatan Kuantitatif, Kualitatif. Bandung: Alfabeta.

Towndrow, P. A., Ling, T. A., \& Venthan, A. M. (2008) Promoting Inquiry Through Science Reflective Journal Writing. Eurasia Journal of Mathematics, Science \& Technology Education, 4(3), 279-283.

Trianto, S. P., \& Pd, M. (2007). Model-model Pembelajaran Inovatif Berorientasi Konstruktivistik. Jakarta: Prestasi Pustaka.
Wahyuni, S., Indrawati, I., Sudarti, S., \& Suana, W. (2017). Developing Science Process Skills And Problem Solving Abilities Based On Outdoor Learning In Junior High School. Jurnal Pendidikan IPA Indonesia, 6(1), 165-169.

Wibowo, P. H., Indrowati, M., \& Sugiharto, B. (2013). Pengaruh Penggunaan Modul Hasil Penelitian Bentos Pada Pokok Bahasan Pencemaran Lingkungan Terhadap Keterampilan Proses Sains Siswa Kelas X Sma Negeri 1 Mojolaban Tahun Pelajaran 2011/2012. Jurnal Pendidikan Biologi, 5(1), 70-80.

Widowati, Asri. 2017. Developing Science Learning Material with Authentic Inquiry Learning Approach to Improve Problem Solving and Scientific Attitude. Jurnal Pendidikan IPA Indonesia, 6(1), 32-40.

Yulianti, D. \& Wiyanto. 2009. Perancangan Pembelajaran Inovatif. Semarang: Lembaga Pengembangan Pendidikan dan Profesi Universitas Negeri Semarang.

Yuniyanti, E. D., \& Sunarno, W. Haryono. 2012. Pembelajaran Kimia Menggunakan Inkuiri Terbimbing dengan Media Modul dan E-Learning ditinjau dari Kemampuan Pemahaman Membaca dan Kemampuan Berpikir Abstrak. Jurnal Inkuiri, 1(2), 112-120. 